\title{
Comparative study to assess the outcome of omitting bladder flap formation from caesarean delivery
}

\author{
Pratiksha Gupta, Suman Kumari*
}

Department of Obstetrics and Gynecology, ESI, PGIMSR, Basaidarapur, New Delhi, India

Received: 14 February 2019

Accepted: 19 February 2019

\section{*Correspondence:}

Dr. Suman Kumari,

E-mail: sumanmishi@gmail.com

Copyright: (C) the author(s), publisher and licensee Medip Academy. This is an open-access article distributed under the terms of the Creative Commons Attribution Non-Commercial License, which permits unrestricted non-commercial use, distribution, and reproduction in any medium, provided the original work is properly cited.

\begin{abstract}
Background: The aim of this study is to evaluate the effects of omitting the step of bladder flap formation at lowersegment caesarean delivery.

Methods: It is a RCT (randomised control trial), non-blinded study conducted in a tertiary care hospital. A total of 104 women who underwent caesarean delivery (elective or emergency) were prospectively randomized to one of the two groups. In the study group $(n=54)$, caesarean was performed without formation of a bladder flap. In the control group $(n=50)$, caesarean was performed with the formation of a bladder flap before the uterine incision.

Results: There were differences of median skin incision to delivery interval (5 versus 6.5 minutes, $\mathrm{P}<0.0001$ ), median total operating time (35 versus 44.5 minutes, $\mathrm{P} 0.0002$ ), and median blood loss (haemoglobin $0.5 \mathrm{versus} 1 \mathrm{~g} / \mathrm{dl}$, $\mathrm{P}$ 0.0001) in favor of the study group. Postoperative incidence of urinary tract infection was reduced in the study group $(1 \%$ versus $9 \%, \mathrm{P}<0.0006)$ and bowel function returned early in the study group (day 2 versus $3, \mathrm{P}<0.0001$ ). Bladder flap formation step was successfully omitted in $(11 / 18,61.11 \%)$ of previous CS (caesarean section) patients in the study group and $(7 / 12,58.33 \%$ ) in control group illustrating that unless required, BF (bladder flap) formation step can even be omitted in previous CS patients.

Conclusions: Omission of the bladder flap provides short term advantages such as reduction of total operating time, incision-delivery interval, and reduced blood loss and that this technique can even be applied in previous caesarean section patients.
\end{abstract}

Keywords: BF (bladder flap), CS (caesarean section), RCT (randomised control trial)

\section{INTRODUCTION}

Caesarean delivery is the most common major surgical procedure performed during pregnancy. In the United States, the rate of caesarean delivery has approached around $25 \%$ and the rate continues to rise. Rates vary considerably between countries and health services. ${ }^{1-3}$ In India, the overall rate of caesarean delivery in 2015-2016 was around $17.2 \%$ (increased from $8.5 \%$ in 2005-2006) and the latest trends show around $35 \% .^{4,5}$ As this rate rises, it is likely to be accompanied by an increase in the rate of surgical complications such as bladder flap hematoma, infection and bladder injury and long-term complications as adhesion formation. Several studies have assessed technical aspects of caesarean delivery but debate continues on whether bladder flap formation is a necessary part of the standard procedure of caesarean delivery. Claims that bladder flap formation gives easy access to the lower uterine segment and avoids bladder injury have not been confirmed in retrospective or randomized trials. ${ }^{6,7}$ On the contrary, some studies suggest that creation of a bladder flap prolongs the 
duration of surgery and may increase the risk of postoperative infection and adhesion formation as well as bladder injury at the time of repeat caesarean. ${ }^{8}$ With the rising incidence of caesarean sections, there is the need to employ evidence based techniques to optimize outcomes and minimize complications.

During caesarean section (CS), the vesico-uterine space (VUS) can be easily dissected and sutured during surgical management of bladder flap (BF) in primary CS, as it is composed of sub mucosal tissue with few vessels. In contrast, in the repeat $\mathrm{CS}$, submesothelial fibrosis modifies the VUS, so the surgical management of BF is more difficult and can be complicated. ${ }^{9}$ When VP (visceral peritoneum) is sutured, any retroperitoneal fluid generated in the BF does not drain into the peritoneum and may result in a bladder flap hematoma (BFH) or abscess, and if extensive, possibly to post-CS broadligament edema, hematomas or abscesses. ${ }^{10}$ Faustin et al. ${ }^{11}$ showed VP closure frequently evokes small fluid collections in the upper part of the VUS in the early puerperium.

If the uterine incision is made slightly above the vesicouterine peritoneal fold, the loose connective tissue between the uterus and the urinary bladder allows spontaneous descent of the bladder. During this process, there is no vascular injury. ${ }^{7}$

\section{METHODS}

A total of 104 women were prospectively randomised into study and control group who underwent caesarean delivery in the Department of Obstetrics and Gynaecology at ESI Hospital between January 2018 to December 2018. There were no significant differences between the two groups with respect to maternal and gestational age. Informed consent was obtained from all.

In the study group, lower segment caesarean section was performed in the following way: abdomen was opened by pfanneilstein incision and a low uterine transverse incision was given about 1 to $2 \mathrm{~cm}$ above the vesicouterine peritoneal fold without dissection and formation of a bladder flap. After the delivery of the fetus, placenta was taken out by controlled cord traction, the uterine incision was closed in two layers by suture Vicryl no.1. The visceral and parietal peritoneums were not sutured and the rectus sheath was closed in a continuous fashion by suture (Vicryl no. 1). The subcutaneous fat was closed if the thickness was more than $2 \mathrm{~cm}$, followed by skin closure (silk).

In the control group, caesarean delivery was performed in the same way together with the formation of a bladder flap before the uterine incision. All patients were administered 10IU oxytocin and prophylactic antibiotics at the start of skin incision. All women were offered solid food within 8 hours after caesarean delivery. Institutional ethical clearance was taken.
The following parameters were evaluated: total operating time (from skin incision to closure of the skin), skin incision-delivery time, pre- and postoperative haemoglobin levels (obtained on the first day after delivery), urinary tract infection (confirmed on urine examination) and bowel function defined as postoperative day of first defecation, wound healing, number of days of hospitalization and readmissions. Obstetric (gestational age, indications for caesarean section) and neonatal indicators (birthweight, Apgar score) were recorded.

\section{Inclusion criteria}

- Primiparous or multiparous women with singleton pregnancy with $\mathrm{GA} \geq 34$ weeks

- Multiparous previous one CS woman with singleton pregnancy with $\mathrm{GA} \geq 34$ weeks.

\section{Exclusion criteria}

- Pregnancy with anomalous baby

- Previous 2 or $3 \mathrm{CS}$.

\section{Statistical analysis}

Categorical variables were presented in number and percentage $(\%)$ and continuous variables were presented as mean \pm SD and median. Normality of data was tested by Kolmogorov-Smirnov test. If the normality was rejected, then non parametric test was used.

Statistical tests were applied as follows:

1. Quantitative variables were compared using MannWhitney Test (as the data sets were not normally distributed) between the two groups.

2. Qualitative variables were compared using ChiSquare test/Fisher's Exact test.

A $p$ value of $<0.05$ was considered statistically significant. The data was entered in MS EXCEL spreadsheet and analysis was done using Statistical Package for Social Sciences (SPSS) version 21.0.

\section{RESULTS}

Statistical analyses compared the characteristics and variables of 54 patients in whom bladder flap formation was omitted with those of 50 patients with a standard bladder flap formation.

Table 1 lists patient details and obstetric data. Table 2 lists the indication for caesarean section. Table 3 lists intraoperative and postoperative details of patients. There were significant differences in skin incision to delivery interval, total operating time, and haemoglobin in favour of the study group (Table 3). No woman had urinary tract infection before caesarean. Urinary tract infection was observed in $18 \%$ in the control group and in $1.85 \%$ in the study group $(\mathrm{p}<0.006)$. 
Table 1: Patient details and obstetric data.

\begin{tabular}{|c|c|c|c|}
\hline & $\begin{array}{l}\text { Case } \\
(n=54)\end{array}$ & $\begin{array}{l}\text { Control } \\
(n=50)\end{array}$ & P value \\
\hline Fetal weight & $\begin{array}{l}3 \\
(2.8-3.2)\end{array}$ & $\begin{array}{l}2.9 \\
(2.8-3)\end{array}$ & NS \\
\hline Gestational age & $\begin{array}{l}37.86 \\
(37-39)\end{array}$ & $\begin{array}{l}38.07 \\
(37.143-39)\end{array}$ & NS \\
\hline Maternal age & $\begin{array}{l}24.5 \\
(21-27)\end{array}$ & $\begin{array}{l}24 \\
(21-26)\end{array}$ & NS \\
\hline \multicolumn{4}{|l|}{ Parity } \\
\hline Multiparous & $\begin{array}{l}25 \\
(46.30 \%)\end{array}$ & $\begin{array}{l}13 \\
(26.00 \%)\end{array}$ & \\
\hline Primiparous & $\begin{array}{l}29 \\
(53.70 \%)\end{array}$ & $\begin{array}{l}37 \\
(74.00 \%)\end{array}$ & \\
\hline \multicolumn{4}{|c|}{ Fetal presentation } \\
\hline Breech & $\begin{array}{l}12 \\
(22.22 \%)\end{array}$ & $\begin{array}{l}9 \\
(18.00 \%)\end{array}$ & \multirow{3}{*}{ NS } \\
\hline Transverse & $\begin{array}{l}4 \\
(7.41 \%)\end{array}$ & $\begin{array}{l}4 \\
(8.00 \%)\end{array}$ & \\
\hline Vertex & $\begin{array}{l}38 \\
(70.37 \%)\end{array}$ & $\begin{array}{l}37 \\
(74.00 \%)\end{array}$ & \\
\hline $\begin{array}{l}\text { No. of previous } \\
1 \mathrm{CS}\end{array}$ & $\begin{array}{l}18 \\
(33.33 \%)\end{array}$ & $\begin{array}{l}12 \\
(24 \%)\end{array}$ & \\
\hline
\end{tabular}

$88.8 \%$ women in the study group and $34 \%$ of patient in control group had first defecation on the second postoperative day. No cases of wound infection or wound dehiscence occurred. The median hospitalization time was 6 days in both the groups and no readmissions were observed in both the groups. There were no significant differences between both the groups with respect to birth weight and Apgar score.

Table 2: Indications of caesarean section.

\begin{tabular}{|c|c|c|c|c|}
\hline \multirow{2}{*}{$\begin{array}{l}\text { Indication } \\
\text { of CS }\end{array}$} & \multicolumn{2}{|l|}{ Group } & \multirow{2}{*}{ Total } & \multirow{2}{*}{$\begin{array}{l}P \\
\text { value }\end{array}$} \\
\hline & Case & Control & & \\
\hline Breech & $\begin{array}{l}12 \\
(22.22 \%)\end{array}$ & $\begin{array}{l}6 \\
(12.00 \%)\end{array}$ & $\begin{array}{l}18 \\
(17.31 \%)\end{array}$ & \multirow{11}{*}{ NS } \\
\hline $\begin{array}{l}\text { Failed } \\
\text { induction }\end{array}$ & $\begin{array}{l}4 \\
(7.41 \%)\end{array}$ & $\begin{array}{l}3 \\
(6.00 \%)\end{array}$ & $\begin{array}{l}7 \\
(6.73 \%)\end{array}$ & \\
\hline $\mathrm{FD}$ & $\begin{array}{l}9 \\
(16.67 \%)\end{array}$ & $\begin{array}{l}14 \\
(28.00 \%)\end{array}$ & $\begin{array}{l}23 \\
(22.12 \%)\end{array}$ & \\
\hline $\begin{array}{l}\text { IUGR } \\
\text { with FD }\end{array}$ & $\begin{array}{l}4 \\
(7.41 \%)\end{array}$ & $\begin{array}{l}1 \\
(2.00 \%)\end{array}$ & $\begin{array}{l}5 \\
(4.81 \%)\end{array}$ & \\
\hline MSL & $\begin{array}{l}6 \\
(11.11 \%)\end{array}$ & $\begin{array}{l}2 \\
(4.00 \%)\end{array}$ & $\begin{array}{l}8 \\
(7.69 \%)\end{array}$ & \\
\hline $\begin{array}{l}\text { MSL with } \\
\text { FD }\end{array}$ & $\begin{array}{l}0 \\
(0.00 \%)\end{array}$ & $\begin{array}{l}5 \\
(10.00 \%)\end{array}$ & $\begin{array}{l}5 \\
(4.81 \%)\end{array}$ & \\
\hline $\begin{array}{l}\text { Not willing } \\
\text { for VBAC }\end{array}$ & $\begin{array}{l}10 \\
(18.52 \%)\end{array}$ & $\begin{array}{l}9 \\
(18.00 \%)\end{array}$ & $\begin{array}{l}19 \\
(18.27 \%)\end{array}$ & \\
\hline $\begin{array}{l}\text { PIH, } \\
\text { HELLP }\end{array}$ & $\begin{array}{l}3 \\
(5.56 \%)\end{array}$ & $\begin{array}{l}4 \\
(8.00 \%)\end{array}$ & $\begin{array}{l}7 \\
(6.73 \%)\end{array}$ & \\
\hline $\begin{array}{l}\text { Transverse } \\
\text { lie }\end{array}$ & $\begin{array}{l}4 \\
(7.41 \%)\end{array}$ & $\begin{array}{l}4 \\
(8.00 \%)\end{array}$ & $\begin{array}{l}8 \\
(7.69 \%)\end{array}$ & \\
\hline Others & $\begin{array}{l}2 \\
(3.70 \%)\end{array}$ & $\begin{array}{l}2 \\
(4.00 \%)\end{array}$ & $\begin{array}{l}4 \\
(3.85 \%)\end{array}$ & \\
\hline Total & $\begin{array}{l}54 \\
(100.00 \%)\end{array}$ & $\begin{array}{l}50 \\
(100.00 \%)\end{array}$ & $\begin{array}{l}104 \\
(100.00 \%)\end{array}$ & \\
\hline
\end{tabular}

*FD=fetal distress, IUGR=intra-uterine growth retardation, $\mathrm{MSL}=$ meconium stained liquor, $\mathrm{VBAC}=$ vaginal birth after caesarean section, PIH=pregnancy induced hypertension, HELLP=hemolysis, elevated liver enzymes, low platelet count, $\mathrm{NS}=$ non-significant, ${ }^{*} \mathrm{~S}=$ significant, $\mathrm{Hb}=$ haemoglobin

Table 3: Intraoperative and postoperative details of patients.

\begin{tabular}{|l|l|l|l|}
\hline Details of patients & Case $(\mathrm{n}=54)$ & Control $(\mathrm{n}=50)$ & P value \\
\hline Change in $\mathrm{Hb}(\mathrm{g} / \mathrm{dl})$ & $0.5(0.45-0.5)$ & $1(0.9-1.2)$ & $<0.0001(\mathrm{~S})$ \\
\hline Incision delivery interval $(\mathrm{min})$ & $5(4.167-6)$ & $6.5(6.167-6.667)$ & $0.0001(\mathrm{~S})$ \\
\hline Postoperative day of first defecation & $2(2-2)$ & $3(2-3)$ & $<.0001(\mathrm{~S})$ \\
\hline Total operating time (minutes) & $35(34-40)$ & $44.5(40-45)$ & $0.0002(\mathrm{~S})$ \\
\hline Urinary tract infection & & & \\
\hline No & $53(98.15 \%)$ & $41(82.00 \%)$ & $0.006(\mathrm{~S})$ \\
\hline Yes & $1(1.85 \%)$ & $9(18.00 \%)$ & \\
\hline
\end{tabular}

Table 4: Distribution of patients to bladder flap formed and not formed group.

\begin{tabular}{|l|l|l|l|l|l|}
\hline \multirow{2}{*}{ Bladder flap formed } & Case & Control & Total & P value \\
\hline & No & $47(87.04 \%)$ & $7(14.00 \%)$ & $54(51.92 \%)$ & \\
\cline { 2 - 5 } & Yes & $7(12.96 \%)$ & $43(86.00 \%)$ & $50(48.08 \%)$ & $<.0001$ \\
\hline Total & & $54(100.00 \%)$ & $50(100.00 \%)$ & $104(100.00 \%)$ & \\
\hline
\end{tabular}

Table 4 shows distribution of cases and control in bladder flap formed and non-formed group. Surgical management of BF as outlined in the study and control group could not be followed totally in both the groups. In the study group,
BF had to be created in seven $(7 / 54,12.96 \%)$ patients and in the control group, BF was abandoned in seven $(7 / 50$, $14 \%)$ patients. In all the seven patients in study group in whom BF was created, patients were previous CS and 
bladder was found advanced at the site of incision. In the control group, seven patients in whom bladder flap was not created were posted for caesarean delivery in view of fetal distress and there was need to deliver the baby as quick as possible.

Table 5 shows distribution of previous CS patients in BF formed and not formed group. Bladder flap formation step was successfully omitted in eleven $(11 / 18,61.11 \%)$ of previous CS patients in study group and seven (7/12, $58.33 \%$ ) in control group illustrating that unless required, $\mathrm{BF}$ formation step can even be omitted in previous CS patients.

Table 5: Distribution of previous CS patients in BF formed and not formed group.

\begin{tabular}{|l|l|l|}
\hline Bladder flap & Case $(\mathrm{n}=18)$ & Control $(\mathrm{n}=12)$ \\
\hline Not- formed & $11(61.11 \%)$ & $7(58.33 \%)$ \\
\hline Formed & $7(38.88 \%)$ & $5(41.66 \%)$ \\
\hline *CS=caesarean section, BF=bladder flap & \\
\hline
\end{tabular}

Results of present study showed significant differences in median skin incision to delivery time, total operating time, haemoglobin difference, incidence of urinary tract infection in favour of study group and also showed that omission of BF formation step can even be applied to previous CS patients.

\section{DISCUSSION}

In the pre-antibiotic era, the rationale for the bladder flap formation was to enable the surgeon gain access to the lower uterine segment while minimizing injury to the bladder. ${ }^{12}$ Its subsequent closure was supposed to protect the peritoneal cavity from intrauterine infection. It has been seen that disruption of the autonomic innervations may occur on creation of the bladder flap which can result in an increased incidence of urinary retention and hence infection and thick adhesions in the lower uterine segment that may lead to difficulty in subsequent caesarean delivery. ${ }^{13}$ With the use of antibiotics, closure of the bladder flap has been demonstrated to be unnecessary and associated with increased morbidity as febrile morbidity, adhesions and upward dislocation of the urinary bladder. ${ }^{14,15}$ Data on the role of the bladder flap in caesarean section is very limited. Pelosi and Ortega introduced elimination of the bladder dissection in CS. ${ }^{16}$ Wood et al, compared Pelosi technique with Yale's traditional methods and confirmed the utility of Pelositype CS, but they also did not investigate single modification of omission of bladder flap. ${ }^{17}$ Hohlagschwandtner et al concluded that CS without the formation of a bladder flap provides a number of significant short-term benefits. ${ }^{11}$ But they did not evaluate long-term effects such as adhesions and fertility. Chigbu et al concluded that omission of the bladder flap formation at CS is associated with good short- and longterm outcomes. ${ }^{18}$ Because the omission of the bladder flap causes less trauma and vascular injury, subsequently fewer additional hemostatic sutures are required. ${ }^{19}$ In emergency caesarean sections, where rapid delivery is the goal, the bladder flap is commonly omitted. Omission of the bladder flap prevents the incision from being made too low, which prevents rupture of cervix when it is fully dilated. Bladder injuries are rare complications of caesarean but when they occur are usually caused by surgical difficulty encountered while developing the bladder flap. ${ }^{20}$ The lower rate of postoperative microhematuria in both studies also reflects a reduced manipulation and trauma of the urinary bladder. ${ }^{11,18} \mathrm{By}$ an examination of the literature, Stark affirms that the closuring of VP possibly leads to a pocket formation on the VUS, with a subsequent hematoma formation, while Nagele et al, reported a higher rate of febrile morbidity and cystitis in the closed parietal peritoneum group, probably due to the formation of sub-peritoneal pockets resulting from the suture; these pockets could fill with blood and wound secretions from the uterine incision and serve as nutrient media for bacteria. ${ }^{15,21}$ Woo et al, investigated the pelvis after CS and vaginal delivery by MRI and found a pocket collection adjacent to the low transverse uterine suture formed by the suture of the loose reflection of the peritoneum (serosa) that covers the uterus. ${ }^{22}$ Maldjan et al evaluated these collections by MRI in uterine incision sites, demonstrating findings consistent with asymptomatic and sub-acute hematoma, as a usual finding in post-CS women by closed visceral peritoneum. ${ }^{23}$ Present study examined whether there are any short-term benefits in eliminating the bladder flap at caesarean delivery. present findings indicate that caesarean delivery without the formation of a bladder flap provides a number of significant short term benefits as reduced skin incision to delivery interval, total operating time, and decreased incidence of urinary tract infection and early resumption of bowel function. In addition, the omission of the bladder flap technique can safely be applied to previous caesarean section patients and prevents the incision from being made too low. Because the omission of the bladder flap is a new modification, there are no long-term data relating to future pregnancies. Further studies are required to investigate the safety of this technique with respect to subsequent pregnancies and trial of labor. Considering for any effect on delivery of the infant, throughout the study period; no problems were encountered in either group. Recently, a short operating time was shown to reduce the risk of developing mild ileus symptoms in early-fed women after caesarean. The lower rate of postoperative urinary tract infection also reflects a reduced manipulation and trauma of the urinary bladder. The median hospital stay was of 6 days. Authors observed no postoperative ileus among the study population and the practice of non-closure of the peritoneum does not appear to promote adhesions.

\section{CONCLUSION}

The results of present study demonstrate that the omission of the bladder flap provides short term benefits such as reduction of total operating time, incision- 
delivery interval, reduced blood loss, and decreased incidence of urinary tract infection. In addition, present study also illustrates that omission of BF technique can safely be applied to previous caesarean section patients. Long-term effects remain to be evaluated. With the increasing numbers of caesarean deliveries, eliminating unnecessary and potentially harmful steps will reduce morbidity, improve outcomes and save costs. Further, present study shows that omission of the bladder flap in both primary and repeat caesarean sections were associated with shorter operating time without a significant increase in intraoperative and postoperative complications.

Funding: No funding sources

Conflict of interest: None declared

Ethical approval: The study was approved by the Institutional Ethics Committee

\section{REFERENCES}

1. Dumont A, de Bernis L, Bouvier-Colle MH, Breart G. Caesarean section rate for maternal indication in sub-Saharan Africa: a systematic review. Lancet. 2001;358:1328-33.

2. Murray SF, Pradenas FS. Health sector reform and rise of caesarean birth in Chile. Lancet. 1997;349:64.

3. Pai M, Sundaram P, Radhakrishnan KK, Thomas K, Muliyil JP. A high rate of caesarean sections in an affluent section of Chennai: is it cause for concern? Natl Med J India. 1999;12:156-8.

4. International Institute for Population Sciences (IIPS) and Ministry of Health and Family Welfare. National Family Health Survey-4 (NFHS-4), India-Factsheet.

5. International Institute for Population Sciences (IIPS) and Macro International 2007. National Family Health Survey-3 (NFHS-3), 2005-2006: India: Volume 1, Mumbai.

6. Malvasi A, Tinelli A, Gustapane S, Mazzone E, Cavallotti C, Stark Jr M, et al. Surgical technique to avoid bladder flap formation during cesarean section. G Chir. 2011;32(11/12):498-503.

7. Hohlagschwandtner M, Ruecklinger E, Husslein P, Joura EA. Is the formation of a bladder flap at cesarean necessary? A randomized trial. Obstet Gynecol. 2011;98(6):1089-92.

8. Malvasi A, Tinelli A, Guido M, Cavallotti C, Dell'Edera D, Zizza A, et al. Effect of avoiding bladder flap formation in cesarean section on repeat cesarean delivery. Eur J Obstet Gynecol Reprod Biol. 2011;159(2):300-4.

9. Bamigboye AA, Hofmeyr GJ. Closure versus nonclosure of the peritoneum at caesarean section. Cochrane Database Syst 5 Rev. 2003;CD000163.

10. Lev-Toaff AS, Baka JJ, Toaff ME, Friedman AC, Radecki PD, Caroline DF. Diagnostic imaging in puerperal febrile morbidity. Obstet Gynecol. 1991;78:50-5.

11. Faustin D, Minkoff H, Schaffer R, Crombleholme W, Schwarz R. Relationship of ultrasound findings after caesarean section to operative morbidity. Obstet Gynecol. 1985;66:195-8.

12. Faricy PO, Augspurger RR, Kaufman JM. Bladder injuries associated with cesarean section. J Urol. 1978;120(6):762-3.

13. Pelosi MA 2nd, Pelosi MA 3rd. Risk factors for bladder injury during cesarean delivery. Obstet Gynecol. 2005;105(4):900-1.

14. Woyton J, Florjanski J, Zimmer M. Nonclosure of the visceral peritoneum during Cesarean sections. Ginekol Pol. 2000;71(10):1250-4.

15. Nagele F, Karas H, Spitzer D, Staudach A, Karasegh $\mathrm{S}$, Beck A, et al. Closure or nonclosure of the visceral peritoneum at cesarean delivery. Am J Obstet Gynecol. 1996;174(4):1366-70.

16. Pelosi M, Ortega I. Cesarean section: Pelosi's simpliwed technique. Rev Chil Obstet Gynecol. 1994;59(5):372-7.

17. Wood R, Simon H. Oz Ali-Utku. Pelosi-Type vs. traditional cesarean delivery. A prospective comparison. J Reprod Med. 1999;44:788-95.

18. Chigbu C, Ezeome I, Iloabachie G. Non-formation of bladder Xap at cesarean section. Int J Gynaecol Obstet. 2006;95:284-5.

19. Soper D, Brockwell W, Dalton H. The importance of wound infection in antibiotic failures in the therapy of postpartum endometritis. Surg Gynecol Obstet. 1992;174:256.

20. Burke J II, Gallup D. Incisions for gynaecologic surgery. In: Rock JA, Jones HW III, eds. Telinde's operative gynaecology. Lippincott Williams and Wilkins, Philadelphia; 2003:255-290.

21. Stark M. Technique of cesarean section: the Misgav Ladach method. In: Popkin DR, Peddle L, eds. Women's health today. prospective on current research and clinical practice. Montreal: Parthenon Publishing Group; 1994:81-85. Proceedings of the XIV FIGO World Congress of Gynecology and Obstetrics, New York London.

22. Woo GM, Twickler DM, Stettler RW, Erdman WA, Brown CE. The pelvis after cesarean section and vaginal delivery: normal MR findings. Am J Roentgenol. 1993;161:1249-52.

23. Maldjan C, Adam R, Maldjan J, Smith R. MRI appearance of the pelvis in the post caesarean section patient. Magn Reson Imaging. 1999;17:223-7.

Cite this article as: Gupta $\mathrm{P}$, Kumari S. Comparative study to assess the outcome of omitting bladder flap formation from caesarean delivery. Int J Reprod Contracept Obstet Gynecol 2019;8:882-6. 